\title{
A Proposed Quantitative Credit-Rating Methodology For South African Provincial Departments ${ }^{1}$
}

\author{
Erika Fourie and Tanja Verster \\ Centre for Business Mathematics and Informatics, North-West University \\ Gary Wayne van Vuuren \\ Extraordinary professor at the School of Economics, North-West University \\ Accepted: January 2016
}

The development of subnational credit-rating methodologies affords benefits for subnationals, the sovereign and its citizens. Trusted credit ratings facilitate access to financial markets and above-average ratings allow for the negotiation of better collateral and guarantee agreements, as well as for funding of, for example, infrastructure projects at superior (lower) interest rates. This paper develops the quantitative section of a credit-rating methodology for South African subnationals. The unique characteristics of South African data, their assembly, and the selection of dependent and independent variables for the linear-regression model chosen, are discussed. The methodology is then applied to the provincial Department of Health using linearregression modelling.

Key words: subnational governments, credit ratings, linear regression, Department of Health, payment behaviour

JEL: C31, E02, H51, 75

\section{$1 \quad$ Introduction}

Subnational governments are those tiers of government and public entities whose authority is subordinate to the sovereign or national government. These include states, provinces, public-utility companies, counties, cities, towns, school districts, and other special-purpose government entities which are permitted to incur debt (Liu \& Waibel, 2008:20). South African subnationals are defined as provincial governments and provincial departments for the purpose of this paper.

Explosive increases in urbanisation - particularly in developing countries - have emphasised the need for large infrastructure investments, yet fiscal funding and subnational governments' own-tax revenues are seldom sufficient to fund these large investments. As a result, subnational governments are forced to enter the financial market (Liu \& Waibel, 2008:1). Trusted credit ratings facilitate access to these markets and provide an effective way of securing otherwise inaccessible infrastructure-investment funding.

Credit ratings reflect the gradings of borrowers' abilities to meet their financial obligations timeously. These ratings, which rely on independently audited public financial reports, strengthen fiscal transparency and encourage sensible budget and financial management, as well as good governance (Liu \& Tan, 2009:3).

As at October 2015, none of South Africa's subnationals were being credit-rated and no subnational credit-rating methodology then existed. This paper reviews the data and methodology required to the develop quantitative sections of subnational credit-rating methodologies for South Africa's subnationals (using linear regression) and applies the selected methodology specifically to the Department of Health of each of South Africa's nine provinces.

The influence of sovereign credit ratings on subnational credit ratings and an overview of credit-rating methodologies as applied by the three largest international credit-rating agencies (Moody's, Standard and Poors and FitchRatings) are to be found in Fourie, Styger, De La Rey and Van Vuuren (2013:80-84). In addition, Fourie et al. (2013:86-89) discuss possible approaches for subnational credit ratings by providing examples from Canada, Australia and India. Interesting 
observations are drawn from comparing the different, documented credit-rating methodologies. One observation is the five broad factors into which the information used by the three largest international credit-rating agencies to assess the creditworthiness of subnationals can be grouped (Liu \& Tan, 2009:5). Another is the difference in the importance of quantitative and qualitative information for developed and developing countries. Typically, in a developed country, the quantitative and qualitative information will be equally important, as opposed to the situation in developing countries where the quantitative information only equates to 30 per cent of a credit rating and the qualitative information to 70 per cent of a credit rating (Moody's 2007:34). Both of these observations apply for the remainder of this paper.

With this work in place, we present only a reminder of the salient background, and, instead, investigate the requisite data and propose a possible coherent methodology for credit-rating subnationals with direct application to a South African provincial department.

The remainder of the paper is structured as follows: In Section 2, the data and the methodology used to develop the quantitative section of credit-rating methodologies are discussed. These include the compilation of the two health data sets and a brief overview of linear-regression modelling. Section 3 provides the methodology used to develop the linear-regression models, also called payment-behaviour models, using the two data sets. In Section 4, three model advancement techniques, that is, using subject knowledge as a variable selection method, including interactions between the independent variables in the models and excluding outliers from the data, are investigated. In Section 5, subnational credit ratings and their policy implications in South Africa are discussed, Section 6 concludes this paper.

\section{Data and methodology}

Liu and Tan (2009:33-34) caution that data in inconsistent formats cause problems when developing a subnational credit-rating methodology. For this reason, much attention has been paid to the identification of reliable data sources. South Africa's provincial governments' financial records and record keeping are regulated by the National Treasury of South Africa (National Treasury), so most of the data used to develop the quantitative section of the credit-rating methodology for South Africa's subnationals (focusing on provincial departments) employ this source.

The three largest international credit-rating agencies are FitchRatings (Fitch), Moody's Investors Services (Moody's) and Standard and Poor's (S\&P). The three largest international credit-rating agencies all generate generic, subnational credit-rating methodologies. These can be used to determine the creditworthiness of any subnational government, regardless of the area over which the subnational government presides. The rating criteria used by the three rating agencies can be divided into five broad factors (Liu \& Tan, 2009:11-14).

Note that, theoretically, these can be applied to South Africa's provincial governments, departments and municipalities owing to the generic definitions of subnationals (local and regional governments). However, no provincial government or department in South Africa has a Moody's/ Fitch/S\&P rating. Section 2.1 will also show that not all of the data used in these methodologies are available in the South African subnational context.

The data requirements for this study were based on the information used in existing subnational credit-rating methodologies, especially the broad factors. These five factors are the subnational's economic conditions, the fiscal performance of the subnational, the financial and debt position of the subnational, the management quality and strength of subnational institutions, as well as the influence of the sovereign factors, intergovernmental relations and fiscal arrangements on the subnational (Liu \& Tan, 2009:5). The aim was to include variables representing the four relevant broad factors (the fifth factor was omitted, since all the departments reside within the same country and the outcome of the factor will therefore be the same) in the final regression models.

\subsection{Data sources}

An investigation was conducted to identify possible sources of the required information. The sources used were confirmed by the National Treasury and a financial institution as part of a 
workshop held at the National Treasury in 2013 (National Treasury, 2013c). The reports used are compiled by four different institutions: the provincial departments, the National Treasury, Statistics South Africa (StatsSA), and the Auditor-General of South Africa (Auditor-General).

\subsubsection{Annual reports of provincial departments}

These reports are not compiled per provincial government, but per department positioned within the provincial governments. The matter was discussed during the workshop held at the National Treasury in 2012 (National Treasury, 2012). It was recommended that the focus should be on provincial departments instead of provincial governments. The Department of Health was selected as an exemplary department for this paper. This department was chosen since its total expenditure equates to a considerable portion of the provinces' total expenditure. In the 2012/2013 financial year, the Department of Health's total expenditure equated to 31 per cent of the provinces total expenditure (National Treasury, 2013a:3).

The annual reports of the provincial departments should be easily accessible, but problems were experienced in gaining electronic access to some of these. A total of 54 annual reports were collected and captured manually.

\subsubsection{National Treasury reports}

The following reports are assembled on a regular basis by the National Treasury itself, and were also used:

- Fourth quarter year to date provincial budgets and expenditure report (preliminary outcome) 06/07-10/11 (National Treasury, 2007 to 2011); and

- Provincial statements of receipts and payments for the 4th quarter (end March 2007 to 2011) (National Treasury, 2007 to 2011).

\subsubsection{Stats $S A$}

The data needed to portray the economic conditions in the province as well as population information per province were sourced from information provided by Stats SA. The data sourced from this institution were:

- Gross domestic product. Annual estimates 2003-2012. Regional estimates 2003-2012. 3rd quarter 2013 (Stats SA, 2013); and

- the interactive data set containing the mid-year population estimates by province, gender, age group and year in Microsoft Excel (Stats SA, 2012).

Note that the data obtained from these sources were estimates and not final values. Also, the associated dates did not correspond to the rest of the reports' dates. The dates associated with these sources were calendar years (January to December), and the dates relating to the other sources were financial years (April to March). The data sets were constructed in such a manner that most of the months overlapped. For example, January to December 2006 will overlap with April 2006 to March 2007.

\subsubsection{Auditor-General's consolidated general reports on the national and provincial audit outcomes}

The last data requirement, that is, the inclusion of information indicating management quality and institutional strength, was addressed by using reports compiled by the Auditor-General. The reports used are: the consolidated general reports on the national and provincial audit outcomes of 2006/2007 to 2010/2011 (Auditor-General, 2007-2011).

\subsection{Data characteristics and problems}

The required data were captured manually and data-error identification and rectification measures were applied as an iterative process throughout the data-compilation and the model-development phases. Five years' data were gathered from each of the sources, equating to 45 data points. 
The sourced data posed challenges when used to develop the quantitative section of a subnational credit-rating methodology. These challenges include:

- The changing formats of the Auditor-General's reports limited the information that could be used from these reports.

- Credit ratings are typically updated on a regular basis to adjust for changing risk situations (Liu \& Tan, 2009:14-15), yet most of the reports used are only made available on an annual basis (the only sources that are updated quarterly are the National Treasury reports). Ideally, all the required information should be available at least quarterly.

- The outdated information contained in the available reports also posed a challenge. For example, if the developed credit-rating methodology is applied in 2014, the latest available annual reports (as at September 2014) contain information relating to the financial year April 2012 to March 2013. Hence, credit ratings derived from these reports will be based on information up to two years old.

- The annual reports are compiled per provincial department, not per provincial government. Although it should be possible to aggregate these data, the aggregation and the data-gathering process pose difficulties mainly because of the difference in the number of departments that reside within the provincial governments.

- South Africa's provincial departments use the cash-based accounting system. The application of the cash-based accounting system resulted in insufficient information available to provide an indication whether a department's debt obligations were paid in full and on time. This is required, as it indicates a department's capacity and willingness to repay debt obligations in full and on time, as per the definition of credit ratings provided by Liu and Tan (2009:4). Instead, a proxy for the required information had to be used.

These challenges could be alleviated by some amendments to government policies, and recommendations are provided in Section 5.

\subsection{Data-set construction}

The required information, based on the literature study, was gathered from each of the data sources discussed earlier. Two different data sets were created, one with the time variable included (HT) as an independent variable, and the other without the time variable $(\mathrm{H})$.

Since no provincial-level annual reports were available, it was decided to focus rather on provincial departments instead - specifically the Department of Health. Some of the other source data were on a provincial level. Approximately 70 per cent of the information used is on a department level and the other information is at a provincial level.

The constructed data sets contain only quantitative information. This relates to the principle of using only 30 per cent of quantitative information for rating purposes in developing countries (see Fourie et al. (2013) for a detailed discussion regarding the 30 per cent quantitative as opposed to 70 per cent qualitative principle). Therefore, the models developed based on the information discussed in this paper should only equate to 30 per cent of a final credit rating. The other 70 per cent of the final credit rating should be based on qualitative information, and this may be taken into account as an intuitive overlay.

Warner (2008:125) states that analysis based on data containing errors can lead to misleading results. Since data were captured manually, special care was taken to identify and correct data errors. Error identification and rectification measures were applied iteratively.

The methodology, dependent variable and independent variables used to develop the models are discussed next.

\subsection{Methodology: Linear-regression modelling}

Several statistical methods are available for the development of credit-rating predictions (Hwang, Chung \& Chu, 2010:2). Examples of these methods are linear-regression modelling, multiple discriminant analysis, ordered linear probit modelling, and linear logit modelling. Linear-regression 
modelling was chosen to predict the quantitative part of the credit ratings for South African provincial departments. Obviously, other modelling techniques will be suggested as future research. See, for example, the study of Novotna (2012:448) that compared the use of discriminant analysis, logistic regression and decision trees for the estimation of credit-rating models and found that all methods were suitable for credit-rating modelling, with discriminant analysis and logistic regression models being found to be relatively simple to use and to achieve a high classification ability (Novotna, 2012:455).

Hair, Black, Babin, Anderson and Tatham (2006:169) describe linear regression as a general statistical technique that is used to analyse the relationship between one single dependent variable and a number of independent variables. Pallant (2007:148) states that it is a family of techniques used to explore the relationship between one dependent variable and several independent variables.

Linear-regression models can be used to explain the variance of the dependent variable or for prediction purposes. It is important to note that, in order to forecast, the independent variables used to predict the dependent variable for the next year have to be lagging by a year. This also applies to this work, since the aim is to predict the provincial departments' credit ratings for the next financial year (e.g. 2013/2014) based on this financial year's data (e.g. 2012/2013).

The principal advantage of linear regression is its simplicity, interpretability, scientific acceptance, and widespread availability (Chambers \& Dinsmore, 2014:5). Linear regression is also widely performed using statistical software packages and business intelligence tools (Chambers \& Dinsmore, 2014:6). Moody's (2014:5) states that another advantage of using linear-regression modelling is that the parameter estimates are readily available. A further advantage of using linear regression is easy computation and implementation (Moody's 2006:2). However, a disadvantage of using linear-regression modelling is that intuition is lost when too many independent variables are included in the final model (Moody's, 2014:5).

The results of a linear-regression model can be summarised as credit ratings that are graded by symbols such as AA-, BBB+ and Caal. These symbols are used by credit-rating agencies to indicate relative rankings of creditworthiness. An issuer or issue with a higher ranking is considered to have a better credit worthiness than an issuer or issue with a lower ranking; in other words, higher-ranked issuers or issues will default less frequently than issuers or issues ranked lower, assuming that everything else remains the same (S\&P, 2009:4). The aim of the models developed in this paper is to rank South Africa's subnationals (specifically the Departments of Health) in terms of future payment behaviour.

\subsubsection{Dependent variable}

The ultimate aim of a credit-rating methodology is to predict default that can be grouped into credit ratings. A common definition of default used is that a client is unlikely to honour its credit obligation if such client is more than 30,60 or 90 days in arrears with regard to its credit obligation. In order to align the developed credit-rating methodologies to this definition, the desired dependent variable is the number of days or months in arrears. The focus of the cash-based accounting system used by the provincial departments is not to make sure that bills are paid on time but of the amount of cash in the bank. Therefore, the number of days or months in arrears is not reflected in the departments' financial statements contained in the annual reports.

A workshop was arranged with the National Treasury to find an alternative measure which could be used as an indication for payment behaviour. It was suggested that the accruals in excess of 30 days figure that are currently reflected in the provincial financial statements should be used (National Treasury, 2012). This number reflects the rand value of all invoices not paid within 30 days from the invoice date. This is of interest, since the regulations made in terms of the Public Finance Management Act 1 of 1999 stipulate that creditors have to be paid within 30 days of the receipt of the invoice (South Africa, 2006:22).

The rand value of the accruals (in excess of 30 days) are divided by total expenditure in order to make them comparable between departments. This is viewed as a proxy for payment behaviour, that is, to assess whether the departments have been meeting their debt obligations. A high value 
of this ratio indicates bad payment behaviour, since it points to a large portion of total expenditure that is still outstanding after 30 days. The lower the value of this ratio, the better the payment behaviour, since this, on the other hand, indicates that the accruals 30 days plus are proportionally lower than the total expenditure. Thus an increase in this ratio indicates worsening payment behaviour and a decrease indicates improving payment behaviour.

\subsubsection{Independent variables}

The independent variables available for linear-regression modelling purposes are documented in Table 1. The HT data set contained 41 independent variables and the $\mathrm{H}$ data set only 40 , since the time variable was omitted from this data set. Both data sets contained 45 data points.

Table 1

Summary of the independent variables available for linear-regression modelling purposes

\begin{tabular}{|c|c|c|c|}
\hline Source & Variable & Description & Broad factor \\
\hline \multirow{9}{*}{ Constant } & Indicator_EC & 1 = Eastern Cape, 0 = all others & \multirow{9}{*}{ Indicator } \\
\hline & Indicator_FS & $1=$ Free State, $0=$ all others & \\
\hline & Indicator_Gau & 1 = Gauteng, 0 = all others & \\
\hline & Indicator_KZN & $1=$ KwaZulu-Natal, 0 = all others & \\
\hline & Indicator_Lim & 1 = Limpopo population, 0 = all others & \\
\hline & Indicator_Mpu & $1=$ Mpumalanga, $0=$ all others & \\
\hline & Indicator_NW & $1=$ North West, $0=$ all others & \\
\hline & Indicator_NC & $1=$ Northern Cape, $0=$ all others & \\
\hline & Indicator_WC & $1=$ Western Cape, $0=$ all others & \\
\hline Derived from financial year & Time & $\begin{array}{l}1=\text { financial year Apr 06-Mar } 07 \\
2=\text { financial year Apr 07-Mar } 08 \\
3=\text { financial year Apr 08-Mar } 09 \\
4=\text { financial year Apr 09-Mar } 10 \\
5=\text { financial year Apr } 10-\text { Mar } 11\end{array}$ & Time \\
\hline \multirow{6}{*}{$\begin{array}{l}\text { National Treasury's 4th quarter year to } \\
\text { date provincial budgets \& expenditure } \\
\text { report (preliminary outcome) }\end{array}$} & In_x3 & $\begin{array}{l}\text { In(departmental total expenditure / departmental } \\
\text { adjusted budget) }\end{array}$ & \multirow{4}{*}{ Fiscal performance } \\
\hline & In_x4 & $\begin{array}{l}\text { In (departmental total expenditure / total } \\
\text { provincial expenditure) }\end{array}$ & \\
\hline & In_x8 & $\begin{array}{l}\text { In(departmental personnel expenditure / } \\
\text { departmental adjusted budget) }\end{array}$ & \\
\hline & In_x9 & $\begin{array}{l}\text { In(departmental personnel expenditure / total } \\
\text { provincial personnel expenditure) }\end{array}$ & \\
\hline & In_x13 & $\begin{array}{l}\text { In(departmental capital expenditure / } \\
\text { departmental adjusted budget) }\end{array}$ & \multirow{2}{*}{$\begin{array}{l}\text { Financial \& debt } \\
\text { position }\end{array}$} \\
\hline & In_x14 & $\begin{array}{l}\text { In(departmental capital expenditure / total } \\
\text { provincial capital expenditure) }\end{array}$ & \\
\hline \multirow{8}{*}{ Provincial departments' annual reports } & In_x27 & $\begin{array}{l}\text { In(departmental annual appropriation of } \\
\text { revenue / total departmental revenue) }\end{array}$ & \multirow{8}{*}{ Fiscal performance } \\
\hline & In_x28_Zmean & $\begin{array}{l}\text { In(departmental own revenue / total } \\
\text { departmental revenue) (missing mean) }\end{array}$ & \\
\hline & Indicator_x28_Z & $\begin{array}{l}0 \text { if departmental own revenue }=0,1 \text { if } \\
\text { departmental own revenue }>0\end{array}$ & \\
\hline & In_x29 & $\begin{array}{l}\text { In(departmental personnel expenditure / } \\
\text { departmental total current expenditure) }\end{array}$ & \\
\hline & In_x30 & $\begin{array}{l}\text { In(departmental personnel expenditure / } \\
\text { departmental total expenditure) }\end{array}$ & \\
\hline & In_x31 & $\begin{array}{l}\text { In(departmental total current expenditure / } \\
\text { departmental total expenditure) }\end{array}$ & \\
\hline & In_x32 & $\begin{array}{l}\text { In(departmental capital expenditure / } \\
\text { departmental total expenditure) }\end{array}$ & \\
\hline & In_x33 & $\begin{array}{l}\text { In(departmental surplus or deficit / departmental } \\
\text { total revenue) }\end{array}$ & \\
\hline \multirow{3}{*}{ Provincial departments' annual reports } & In_x34 & $\begin{array}{l}\text { In(departmental surplus or deficit / departmental } \\
\text { total expenditure) }\end{array}$ & \multirow{3}{*}{ Fiscal performance } \\
\hline & In_x36 & $\begin{array}{l}\text { In(departmental net assets / departmental total } \\
\text { expenditure) }\end{array}$ & \\
\hline & In_x36_Zmean & $\begin{array}{l}\text { In(departmental net assets / departmental total } \\
\text { expenditure) (missing mean) }\end{array}$ & \\
\hline
\end{tabular}




\begin{tabular}{|c|c|c|c|}
\hline Source & Variable & Description & Broad factor \\
\hline & Indicator_x36_Z & $\begin{array}{l}0 \text { if departmental net assets }=0,1 \text { if } \\
\text { departmental net assets }>0\end{array}$ & \\
\hline \multirow{2}{*}{$\begin{array}{l}\text { National Treasury's 4th quarter year to } \\
\text { date provincial budgets \& expenditure } \\
\text { report (preliminary outcome) }\end{array}$} & In_x39 & $\begin{array}{l}\text { In(departmental own revenue actual collection / } \\
\text { departmental adjusted budget) }\end{array}$ & \\
\hline & In_x41 & $\begin{array}{l}\text { In(departmental own revenue collection / total } \\
\text { provincial revenue) }\end{array}$ & \\
\hline \multirow{3}{*}{$\begin{array}{l}\text { National Treasury's provincial } \\
\text { statements of receipts \& payments for } \\
\text { 4th quarter }\end{array}$} & In_x48 & $\begin{array}{l}\text { In(provincial surplus or deficit / provincial } \\
\text { receipts) }\end{array}$ & \\
\hline & In_x49 & $\begin{array}{l}\text { In(provincial surplus or deficit / provincial } \\
\text { payments) }\end{array}$ & \\
\hline & In_x50 & $\begin{array}{l}\text { In(provincial total receipts / provincial total } \\
\text { payments) }\end{array}$ & \\
\hline $\begin{array}{l}\text { Auditor-General's consolidated general } \\
\text { reports on national \& provincial audit } \\
\text { outcomes }\end{array}$ & $x 52$ & $\begin{array}{l}\text { Quality of department's financial reports: } \\
1=\text { clean audit outcome } \\
2=\text { financially unqualified audit opinion } \\
3=\text { qualified audit opinion } \\
4=\text { adverse audit opinion and disclaimer of } \\
\text { audit opinion }\end{array}$ & $\begin{array}{l}\text { Management } \\
\text { quality \& } \\
\text { institutional } \\
\text { strength }\end{array}$ \\
\hline \multirow{2}{*}{$\begin{array}{l}\text { Stats SA's GDP. Annual estimates 03- } \\
\text { 12. Regional estimates } 03-12 \text {. 3rd } \\
\text { quarter } 2013 \text {. Stats SA's interactive } \\
\text { data set containing mid-year population } \\
\text { estimate }\end{array}$} & In_x57 & In(provincial GDP per capita) & \multirow{5}{*}{$\begin{array}{l}\text { Economic } \\
\text { conditions }\end{array}$} \\
\hline & In_x58 & In(provincial GDP per capita growth) & \\
\hline $\begin{array}{l}\text { Stats SA's GDP - annual \& regional } \\
\text { estimates (P0441) }\end{array}$ & In_x59 & In(provincial GDP growth) & \\
\hline \multirow{2}{*}{$\begin{array}{l}\text { Stats SA's interactive data set } \\
\text { containing mid-year population } \\
\text { estimate }\end{array}$} & In_x60 & $\begin{array}{l}\text { In(provincial dependent population / total } \\
\text { population) }\end{array}$ & \\
\hline & In_x61 & In(provincial dependent population growth) & \\
\hline \multirow{3}{*}{$\begin{array}{l}\text { Provincial departments' annual reports } \\
\text { \& Stats SA's interactive data set } \\
\text { containing mid-year population } \\
\text { estimate }\end{array}$} & In_x63 & In(departmental total revenue per capita) & Fiscal performance \\
\hline & In_x64 & \multirow{2}{*}{ In(departmental capital expenditure per capita) } & \multirow{2}{*}{$\begin{array}{l}\text { Economic } \\
\text { conditions }\end{array}$} \\
\hline & In_x65 & & \\
\hline
\end{tabular}

\subsubsection{Broad factor representation}

Seven of the independent variables used were indicators of the economic conditions within a province, 21 independent variables formed part of the fiscal-performance factor, two formed part of the financial- and debt-position factor, and only one variable provided an indication of management quality and institutional strength. The rest of the independent variables were indicator variables and thus did not form part of any of the broad factors (see Figures 1 to 4 for a list of independent variables per broad factor).

Figure 1

List of independent variables in respect of economic conditions within the province

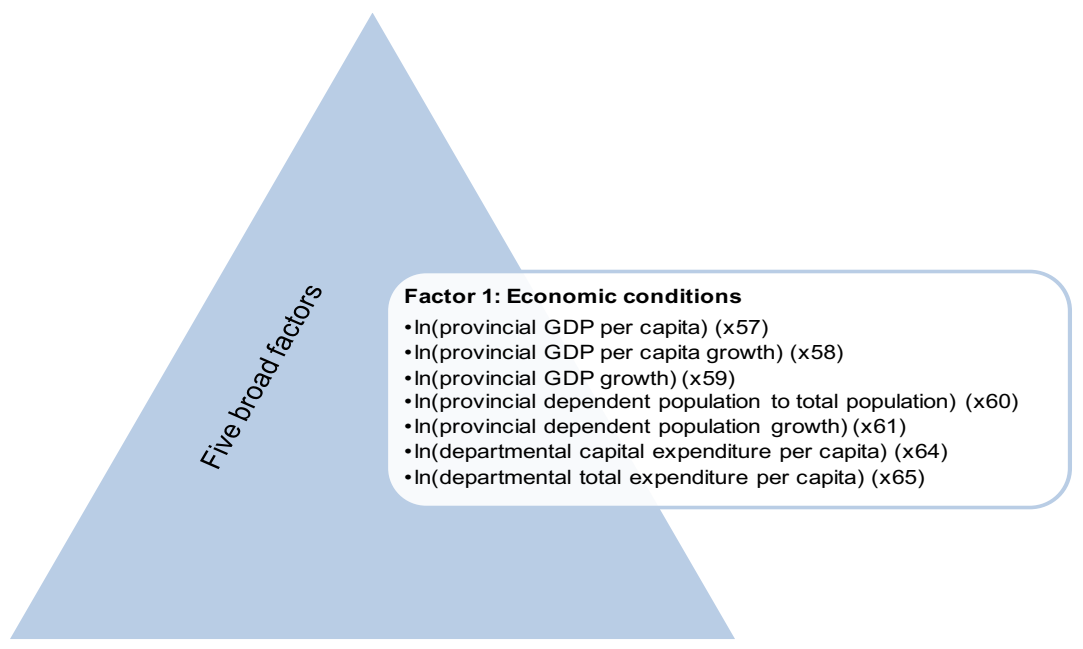


Figure 2

Independent variables representing fiscal performance broad factors

Factor 2: Fiscal performance

- In(departmental total expenditure to departmental adjusted budget) $(\times 3)$

- In(departmental total expenditure to total provincial expenditure) (x4)

- In(departmental personnel expenditure to departmental adjusted budget) $(x 8)$

- In(departmental personnel expenditure to total provincial personnel expenditure) ( $x 9$ )

- Grouped(departmental annual appropriation of revenue to total departmental revenue) (x27)

- In(departmental own revenue to total departmental revenue) (x28_Zmean)

- Indicator_x28_z

- In(departmental personnel expenditure to departmental total current expenditure) (x29)

- In(departmental personnel expenditure to departmental total expenditure) $(\times 30)$

- In(departmental total current expenditure to departmental total expenditure) (x31)

- In(departmental capital expenditure to departmental total expenditure) (x32)

- In(departmental surplus/deficit to departmental total revenue) (x33)

- In(departmental surplus/deficit to departmental total expenditure) (x34)

- In(departmental surplus/deficit to departmental total expenditure) (x34)

- In(departmental

- In(departmental own revenue actual collection to departmental adjusted budget) (x39)

- In(departmental own revenue collection to total provincial revenue) (x41)

- In(provincial surplus/deficit to provincial receipts) (x48)

- In(provincial surplus/deficit to provincial payments) (x49)

- In (provincial total receipts to provincial total payments) $(x 50)$

- In(departmental total revenue per capita) (x63)

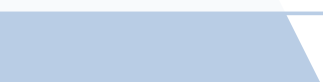

Figure 3

The two independent variables representing the financial and debt position broad factor

Factor 3: Financial and debt position

- In(departmental capital expenditure to

departmental adjusted budget) (x13)

In(departmental capital expenditure to tota

provincial capital expenditure) $(\times 14)$ 
Figure 4

The variable containing the management quality and institutional strength information

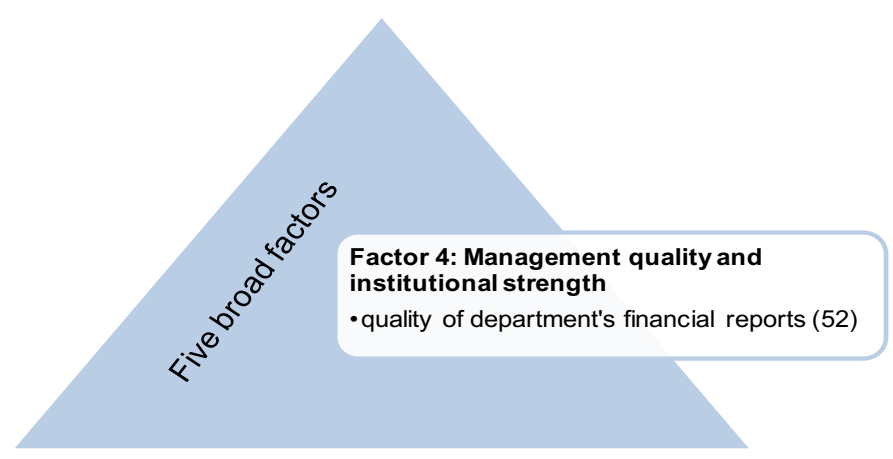

\subsection{Summary of data and methodology}

Although the construction of the data sets was not an initial goal of this paper, it was nevertheless an additional result. These data sets are available on request.

These data and the methodology discussed were used to derive a number of different linearregression models for use as a credit-rating methodology within the South African subnational context in order to predict payment behaviour. Again, the resulting models will contain only quantitative information and can, therefore, only be viewed as the quantitative part of a creditrating methodology.

The number of provincial departments per provincial government differs. In theory, it should be possible to aggregate the data at a provincial government level so as to develop a provincial-level, subnational credit-rating methodology, but, in practice, the unequal number of departments poses difficulties in terms of data collection and aggregation.

An additional observation from this investigation was that the formats of some of the reports used are non-static. This may pose problems with regard to the future use of the developed creditrating methodology. Another key finding was that most data used are only made available on an annual basis. Credit ratings, however, should be updated regularly in order to adjust for changing risk situations. Also, the formats of some of the reports used change year on year. This, too, may pose problems with regard to the future use of the developed credit-rating methodology. Finally, the application of the cash-based accounting system resulted in insufficient information being available to provide an indication whether a department's debt obligations were paid in full and on time. This was required, as it indicates a department's capacity and willingness to repay debt obligations in full and on time. Instead, a proxy for the required information had to be used.

\section{Developing a linear-regression model for the Department of Health}

In order to apply linear-regression modelling to the data, the following steps were taken. Firstly, variable clustering was performed to deal with multicollinearity among the independent variables. The next step was to deal with irrelevant independent variables by using scatter plots of Spearman's correlation versus Hoeffding's D ranks. Lastly, linear-regression modelling based on four different variable-selection techniques was used to develop the payment-behaviour models. Data analysis and output were generated using the SAS Institute Inc. (2011) software.

\subsection{Health with time data set (HT)}

The HT data comprises 45 data points and 41 independent variables. Variable clustering was used to deal with multicollinearity, and the Varclus procedure of the SAS Institute Inc. (2011) software was used to perform the analysis. One variable was chosen from each cluster of variables as the 
cluster representative. The decision was based either on the lowest $R^{2}-$ thus having a high correlation with its own cluster, but low correlations with the rest of the clusters - or on subject knowledge. Decision making based on subject knowledge was recommended by Sanche and Lonergan (2006:91). This resulted in 19 variables, representing all four broad factors, which will be used for the rest of the analysis.

The Corr procedure of the SAS Institute Inc. (2011) software was used to create a scatter plot of the ranks of the Spearman's correlation coefficients of each independent variable with the dependent variable versus ranks of Hoeffding's Ds for each independent variable with the dependent variable. This was used to identify irrelevant variables, that is, independent variables with too low correlations with the dependent variable. This step decreased the number of possible independent variables to 14 .

Four different variable-selection techniques were used to choose the final independent variables from the variables that remained after multicollinearity and irrelevancy were dealt with. The variable-selection techniques used were stepwise selection, forward addition, backward elimination, and best subset. Note that a significance level of 0.1 was set for these variableselection techniques. The analyses were performed by using the Reg procedure of the SAS Institute Inc. (2011) software.

In the case of the HT data set, the four variable-selection techniques resulted in exactly the same model. The detail of this model is provided in Table 2.

Table 2

Linear-regression results of the HT data set

\begin{tabular}{|c|c|c|c|c|c|}
\hline$R^{2}$ & 0.51 & Adj. $R^{2}$ & 0.45 & & \\
\hline Variable & Description & Parameter & $\begin{array}{l}\text { Standardised } \\
\text { estimate }\end{array}$ & $p$-value & $\begin{array}{c}\text { Variance } \\
\text { inflation factor }\end{array}$ \\
\hline Intercept & Intercept & -1.06 & 0.00 & 0.30 & 0.00 \\
\hline Indicator_KZN & $1=\mathrm{KZN}, 0=$ all others & -2.74 & -0.62 & $<.001$ & 1.09 \\
\hline In_x28_Zmean & In(departmental own revenue (missing mean)) & 0.34 & 0.31 & 0.01 & 1.14 \\
\hline Indicator_Mpu & $1=\mathrm{Mpu}, 0=$ all others & -1.32 & -0.30 & 0.01 & 1.09 \\
\hline Indicator_Lim & $1=\operatorname{Lim}, 0=$ all others & -1.18 & -0.27 & 0.03 & 1.08 \\
\hline In_x58 & In(provincial GDP per capita growth) & 0.90 & 0.24 & 0.04 & 1.02 \\
\hline
\end{tabular}

Figure 5

Scatter plot and normality plot of the residual of the HT data set's linear-regression model
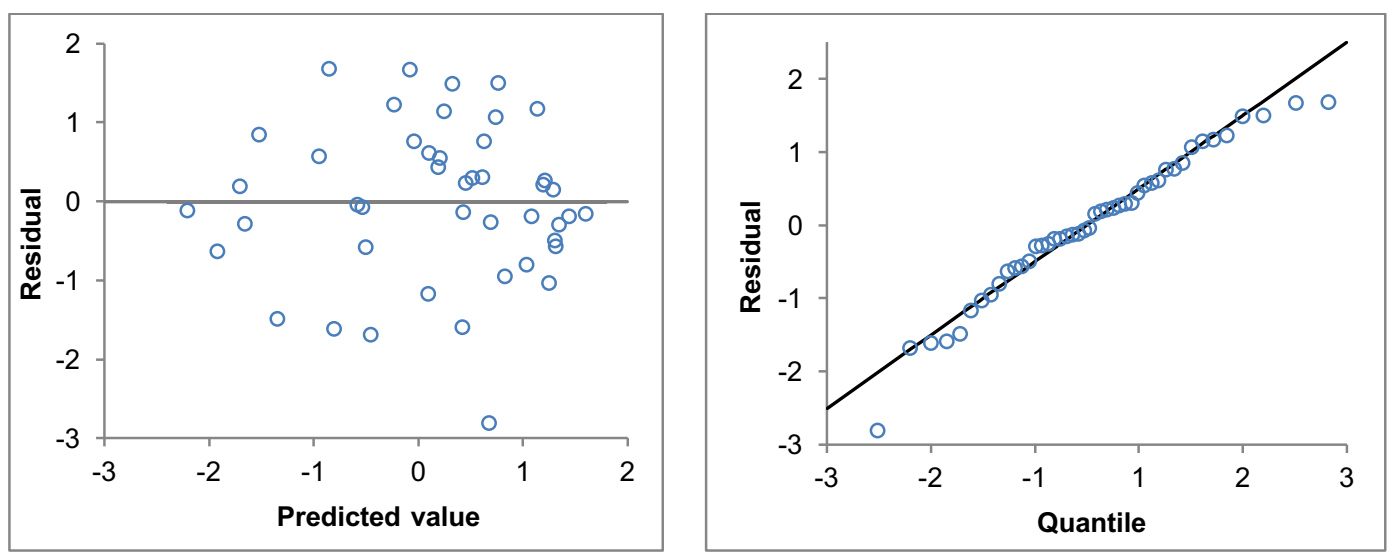

This resulted in the following model:

$\widehat{Y}_{\imath}=-1.06-2.74\left(\right.$ Indicator_KZN $\left._{i}\right)+0.34\left(\right.$ ln_x $_{-} 28 \_Z$ mean $\left._{i}\right)-1.32\left(\right.$ Indicator_Mpu $\left._{i}\right)$

$-1.18\left(\right.$ Indicator_Lim $\left._{i}\right)+0.90\left(\ln \__{-} x 8_{i}\right)$ 
Where $i=1,2, \ldots 9$.

The model has an $R^{2}$ of 0.51 . Thus it explains 51 per cent of the variance of the dependent variable. The $R^{2}$ adjusted for the number of parameters within the model is 0.45 (Table 2 ).

The independent variables, excluding the intercept, are sorted according to importance based on the absolute values of the standardised parameter estimates. Thus the most influential variable is Indicator_KZN.

All the $p$-values of the five independent variables chosen for this model are below 0.1 . The variance inflation factors of the variables range between 1.02 and 1.09 , which is well below the guideline value of 10 suggested by Hair et al. (2006:230). The interpretation of the independent variables' effects on the dependent variable is based on the parameter estimates. An independent variable's parameter estimate indicates the change in the dependent variable per one unit increase of the corresponding independent variable when the other independent variables are held constant (Kutner, Nachtsheim, Neter \& Li, 2005:307). Therefore, when explanations are provided of the independent variables' effects on the dependent variable, it is assumed that all other variables remain constant. The negative signs of the parameter estimates of Indicator_KZN, Indicator_Mpu and Indicator_Lim indicate that the Departments of Health of KwaZulu-Natal, Mpumalanga and Limpopo are better payers than the other provinces' Departments of Health.

As ln_x28_Zmean (departmental own revenue to total departmental revenue) increases, the payment behaviour of the departments worsen. This is indicated by the parameter estimate of 0.34 . A possible explanation is that departmental own revenue is a more volatile source of income than that received directly from national government - depending on the original source of own revenue. Fitch (2011:4) also reviews revenue sources in terms of volatility, diversity and predictability and states that reliance on economically sensitive revenue leads to a credit concern. Thus, if a department's own revenue is generated from an economically sensitive activity, an increase would influence payment behaviour negatively.

The positive parameter estimate of gross domestic product (GDP) per capita growth (ln_x58) indicates than an increase in GDP per capita growth will worsen payment behaviour when considering this model. This contradicts Moody's (2008:15), which states that a high regional GDP per capita is considered a credit positive. However, the growth in GDP can be caused by a decrease in the number of residents in the province; hence the tax base or income base is shrinking and less money is available to pay creditors. This is supported by various other authors (Fitch, 2011:6-7; S\&P, 2010:19; AustraliaRatings, 2014).

The normality, linearity and homoscedasticity assumptions of a linear-regression model can be tested by means of a scatter plot and a normality plot of the residuals. It is evident from Figure 5 that the linear-regression model resulting from the HT data set met the assumptions.

\subsection{Health without time data set $(\mathrm{H})$}

The $\mathrm{H}$ data comprise 45 data points, but one less independent variable than the previous data, since the time variable was excluded from the $\mathrm{H}$ data. Thus 40 independent variables were available for modelling purposes. Variable clustering was used to deal with multicollinearity among the 40 independent variables and resulted in 18 variables that will be used for the rest of the analysis.

The scatter plot of the ranks of the Spearman's correlation coefficients versus Hoeffding's Ds for each of the remaining 18 independent variables with the dependent variable was used to deal with irrelevant independent variables and decreased the number of independent variables available for modelling purposes to 14 . The stepwise and forward selection techniques resulted in the same linear-regression model, and the other two methods resulted in another regression model.

Equation 2 describes this model:

$\widehat{Y}_{l}=-2.33-2.59\left({\text { Indicator_K } Z N_{i}}\right)-0.56\left(x 27\right.$ grouped $\left._{i}\right)-1.35\left(\right.$ Indicator_Lim $\left._{i}\right)+0.88\left(\right.$ ln_ $\left._{1} x 14_{i}\right)$

The $R^{2}$ of 0.49 indicates that the model explains 49 per cent of the variance of the dependent variable. The $R^{2}$ adjusted for the number of parameters within the model is lower at 0.44 . 
Table 3

Stepwise and forward regression of the $\mathrm{H}$ data set

\begin{tabular}{|c|c|c|c|c|c|}
\hline$R^{2}$ & 0.49 & Adj. $R^{2}$ & 0.44 & & \\
\hline Variable & Description & Parameter & $\begin{array}{l}\text { Standardised } \\
\text { estimate }\end{array}$ & $p$-value & $\begin{array}{l}\text { Variance } \\
\text { inflation factor }\end{array}$ \\
\hline Intercept & Intercept & -2.33 & 0.00 & 0.16 & 0.00 \\
\hline Indicator_KZN & $1=\mathrm{KZN}, 0=$ all others & -2.59 & -0.58 & $<.0001$ & 1.13 \\
\hline x27_grouped & $\begin{array}{l}\text { Departmental annual appropriation of } \\
\text { revenue to total departmental revenue } \\
\text { (grouped) }\end{array}$ & -0.56 & -0.33 & 0.01 & 1.11 \\
\hline Indicator_Lim & $1=\operatorname{Lim}, 0=$ all others & -1.35 & -0.30 & 0.01 & 1.08 \\
\hline In_x14 & $\begin{array}{l}\text { In(departmental capital expenditure to total } \\
\text { provincial capital expenditure) }\end{array}$ & 0.88 & 0.22 & 0.08 & 1.12 \\
\hline
\end{tabular}

Figure 6

Dataset H's stepwise and forward models' residual plot
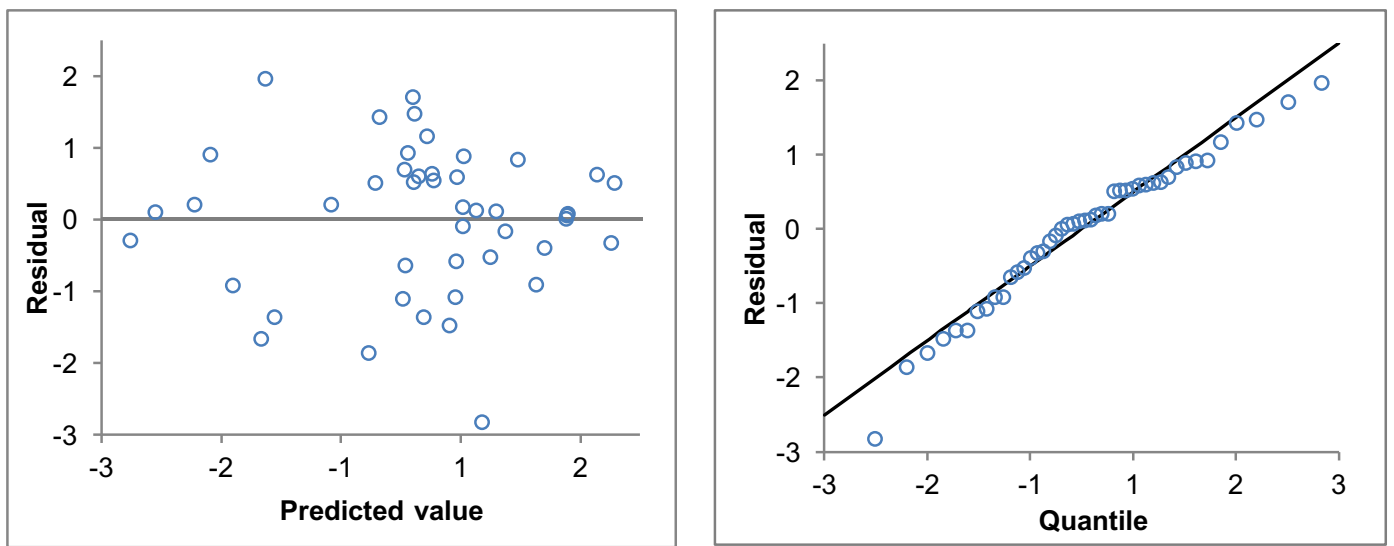

The absolute values of the standardised parameter estimates indicate that the independent variable Indicator_KZN is the most influential (Table 3). This corresponds to the results of the HT data set. The highest $p$-value (ignoring the intercept) is 0.08 , and the highest variance inflation factor is 1.13, which is well below the respective guideline values of 0.1 and 10 . The interpretation of independent variables and their effect on the dependent variable is documented next. Again, one variable at a time will be explained, and it will be assumed that the other variables remain constant. The parameter estimates of variables Indicator_KZN and Indicator_Lim, -2.59 and -1.35 , respectively, indicate that these provinces' Departments of Health are better payers than those of the other provinces.

As departmental annual appropriation of revenue to total departmental revenue (x27_grouped) increases, the payment behaviour of the department improves. This is indicated by the negative parameter estimate of -0.56 . One explanation is that revenue received directly from national government is unwavering as opposed to some sources of departmental own revenue. As stated earlier, Fitch (2011:4) also takes the volatility, diversity and predictability of revenue sources into account, since overdependence on a volatile source would influence payment behaviour in a negative manner. Thus a higher proportion of department annual appropriation of revenue would influence payment behaviour in a positive manner, since this is considered an unwavering source of revenue.

An increase in the ratio departmental capital expenditure to total provincial expenditure, $\ln \_x 14$, leads to a deterioration of payment behaviour. One possible reason for the increase in the ratio is an increase in the department's capital expenditure. If this is the case, payment behaviour could be affected negatively, since capital expenditure is a long-term commitment and therefore may have an undesirable impact on future expenditure flexibility. 
The scatter plot indicates that the model met the underlying assumptions of linearity and homoscedasticity. The residuals are normally distributed (Figure 7).

Table 4

Backward and best subset regression model of the $\mathrm{H}$ data set

\begin{tabular}{|c|c|c|c|c|c|}
\hline$R^{2}$ & 0.54 & Adj. $R^{2}$ & 0.48 & & \\
\hline Variable & Description & Parameter & $\begin{array}{l}\text { Standardised } \\
\text { estimate }\end{array}$ & $p$-value & $\begin{array}{c}\text { Variance } \\
\text { inflation factor }\end{array}$ \\
\hline Intercept & Intercept & 0.07 & 0.00 & 0.92 & 0.00 \\
\hline Indicator_KZN & $1=\mathrm{KZN}, 0=$ all others & -2.43 & -0.55 & $<.0001$ & 1.17 \\
\hline x27_grouped & $\begin{array}{l}\text { Departmental annual appropriation of } \\
\text { revenue to total departmental revenue } \\
\text { (grouped) }\end{array}$ & -0.69 & -0.41 & 0.00 & 1.13 \\
\hline Indicator_Lim & $1=\operatorname{Lim}, 0=$ all others & -1.22 & -0.27 & 0.02 & 1.02 \\
\hline Indicator_x36_Z & $0=$ departmental net assets, $1=$ other & -1.11 & -0.27 & 0.03 & 1.15 \\
\hline$x 52$ & Quality of department's financial reports & 0.48 & 0.24 & 0.04 & 1.14 \\
\hline
\end{tabular}

Figure 7

Residual plots of the $\mathrm{H}$ data set's backward and best subset model
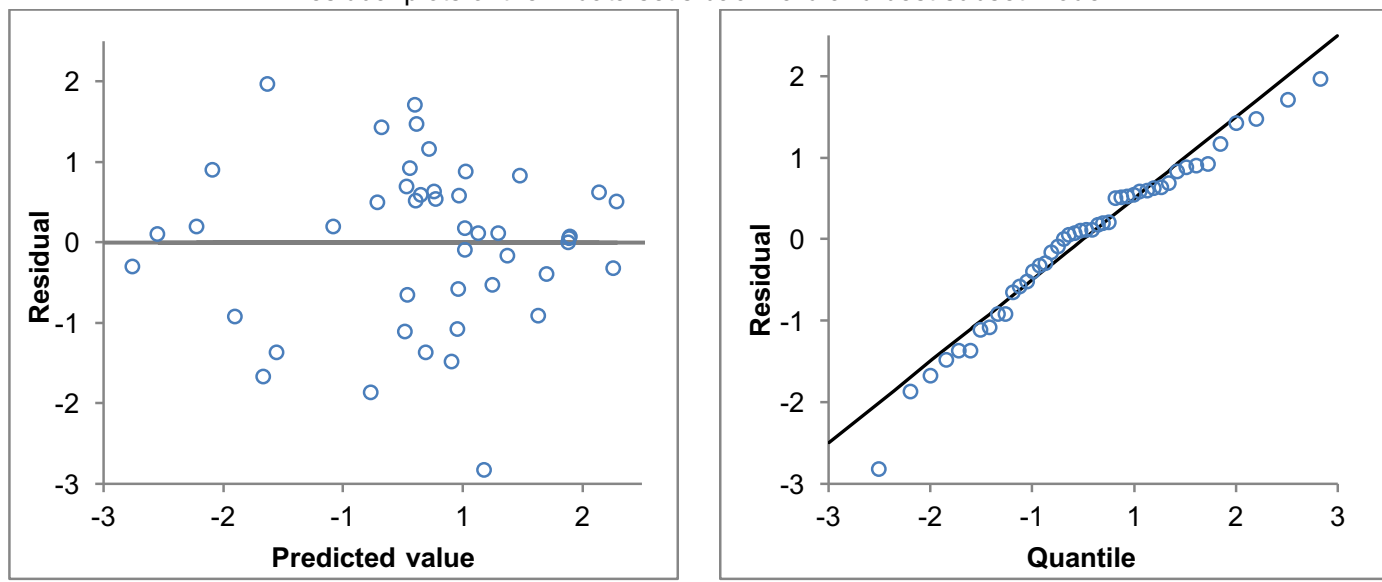

This resulted in the following model:

$\widehat{Y}_{\imath}=0.07-2.43\left(\right.$ Indicator_KZN $\left._{i}\right)-0.69\left(x 27 \_\right.$grouped $\left._{i}\right)-1.22\left(\right.$ Indicator_Lim $\left._{i}\right)$

-1.11 (Indicator_x36_Zmean $i)+0.48\left(x 52_{i}\right)$

The $R^{2}$ and adjusted $R^{2}$ of this model are marginally higher, at 0.54 and 0.48 , respectively, than the previous model values. This is to be expected, since this model includes five independent variables as opposed to the four of the previous model.

Indicator_KZN is the most influential variable included in this model as well. All the $p$-values are below the cut-off of 0.1 . The low variance inflation factors indicate that no multicollinearity exists among the five independent variables. The KwaZulu-Natal and Limpopo provinces' Departments of Health are thus better payers than the other provinces' Departments of Health. Again, as departmental annual appropriation of revenue to total departmental revenue (x27_grouped) increases, the payment behaviour of the department improves.

The negative parameter estimate of Indicator_x36_Z reflects that departments with net assets are better payers than departments without net assets. Generally, the existence of net assets, that is, where assets exceed liabilities, indicates good financial management; hence departments with net assets will be in a better position to make repayments in a timely manner. AustraliaRatings (2014) also reviews assets management as part of its financial-management strategy assessment.

The parameter estimate of 0.48 of $\times 52$ (quality of department's financial reports) shows that, as the quality of financial reporting worsens, the department's payment behaviour also worsens $(1=$ 
clean audit, 2 = financially unqualified audit opinion, $3=$ qualified audit opinion, or $4=$ adverse audit opinion and disclaimer of audit opinion). Good financial reporting indicates good financial management. Three other ratings agencies also examine the quality, transparency, level of detail, timeliness, frequency and audit opinion of a subnational's financial reports (Moody's, 2008:13-14; S\&P, 2010:23-24; DBRS, 2011:10).

Figure 7 indicates that this model adheres to underlying linear-regression modelling assumptions.

\subsection{Summary}

Section 3 documented the methodology used to develop the linear-regression models, or paymentbehaviour models, as well as the results of the models developed using the two data sets. Attention was given to the dependent and independent variables used. The resulting linear-regression models were payment-behaviour models which can be used to derive the 30 per cent quantitative part of a final ranking or credit rating.

The linear-regression models were developed in three steps. Firstly, variable clustering was performed to deal with multicollinearity among the independent variables. Then, irrelevant independent variables were dealt with by using scatter plots of Spearman's correlation versus Hoeffding's D ranks. Lastly, linear-regression modelling based on four different variable-selection techniques was used to develop the payment-behaviour models.

The aim of the models developed was to rank South African subnationals in terms of expected future payment behaviour based on quantitative information.

\section{$4 \quad$ Model advancements}

This section investigates whether certain model advancements can improve the $R^{2}$ values of the linear-regression models presented previously.

In order to improve the linear-regression models, three advancements methods were investigated, namely using subject knowledge as a variable-selection method, including interactions between the independent variables in the models and excluding outliers from the data sets. These methods were only applied to the linear-regression models that resulted from the stepwise variable-selection procedure.

\subsection{Health with time data set (HT)}

The results of using subject knowledge as a variable-selection method, as well as outlier and interaction testing of the HT data set are presented next.

\subsubsection{Subject knowledge as a variable-selection method}

The four variable-selection techniques discussed in the previous section were based on the statistical properties of the independent variables. In other words, variables were selected based on their predictive power (measured in terms of significance levels) with regard to the dependent variable. Alternatively, variables selection can be done by manually entering some independent variables selected by the researcher based on past work or subject knowledge (Field, 2005:161; Osborne, 2008:301).

Thus the model-advancement method investigated in this case entailed ensuring that independent variables from all four broad factors identified by the literature were included in the stepwise models. Although this did result in an improvement of $R^{2}$ from 0.51 to 0.53 , such improvement should be tested in terms of prediction accuracy (see "Suggestions for future research").

\subsubsection{Outliers}

The treatment of outliers depends on the reason for the resulting outlier. If it is due to an error during the data-capturing phase, it should be corrected or deleted from the data set. If the outlier is valid, but is explainable by an exceptional situation, it should only be deleted if there are no 
independent variables in the model that can explain the exceptional situation. If there is no explanation available for an outlier, the analyses should be undertaken with the outlier included and excluded, since neither the inclusion nor exclusion can be warranted (Hair et al., 2006).

Identified outliers were treated in two ways. Firstly, they were investigated during the datacompilation phase as well as in the model-building phase. If these outliers were caused by datacapturing errors, they were corrected. If they involved special circumstances, they were left unchanged.

Secondly, during the model-advancement phase, the M Estimation and least-trimmed squares (LTS) procedures of the SAS Institute Inc. (2011) software were used to identify outliers. The M Estimation procedure focuses on outliers in the dependent variable, and the LTS procedure on outliers in the independent variables. Since no reason to delete these data could be found, models were developed with the outliers included and excluded. The results of the models including the identified outliers were documented in Section 3, and the results of the models excluding outliers are presented in this section. Note that the process followed for models excluding outliers was as follows: once outliers were identified, they were deleted from the data sets and parameter estimates were recalculated.

The effect of the outlier omission on parameter estimates must be assessed once parameter estimates have been recalculated. Similar parameter estimates resulted from these cases.

\subsubsection{Interaction effects}

Another way of improving a linear-regression model is to add interaction effects to the model. The specific interaction terms that formed part of this investigation were two-way interactions and polynomials of the second degree. The results of adding interaction effects to the stepwise model of the HT data set are presented in Table 5. The consequential model contains only interaction variables, except for the intercept, and the $R^{2}$ increased to 0.74 .

Kutner et al. (2005:306-313) state that a model which includes interaction terms is considered to be a complex model, and SAS Institute Inc. (2010:3-59) states that the inclusion of polynomial terms complicates interpretation. Therefore, only high-level descriptions of the effects of the interaction terms on the dependent variable are provided (Table 6).

Table 5

Linear-regression model with interaction effects of the HT data set

\begin{tabular}{|l|c|c|c|c|}
\multicolumn{1}{|c|}{ Variable } & 0.74 & Adj. $R^{2}$ & 0.68 & \\
\cline { 1 - 2 } & Parameter & $\begin{array}{c}\text { Standardised } \\
\text { estimate }\end{array}$ & $\boldsymbol{p}$-value & $\begin{array}{c}\text { Variance inflation } \\
\text { factor }\end{array}$ \\
\hline Intercept & 1.03 & 0.00 & $<.0001$ & 0.00 \\
\hline Indicator_WC_In_x49 & -19.85 & -0.32 & $<0.01$ & 1.11 \\
\hline X27_grouped_indicator_x36_Z & -0.62 & -0.33 & $<0.01$ & 1.26 \\
\hline Indicator_Lim_In_x36_Zmean & 0.60 & 0.37 & $<0.01$ & 1.18 \\
\hline Indicator_KZN_In_x48 & -32.18 & -0.60 & $<.0001$ & 1.12 \\
\hline Indicator_Mpu_In_x57 & -0.15 & -0.36 & $<0.01$ & 1.13 \\
\hline Indicator_Lim_In_x50 & -65.09 & -0.35 & $<0.01$ & 1.13 \\
\hline Indicator_FS_In_x33 & -22.70 & -0.18 & 0.005 & 1.06 \\
\hline x27_grouped_In_x34 & -13.93 & -0.29 & $<0.01$ & 1.22 \\
\hline
\end{tabular}

\subsubsection{Combining the effect of interaction effects and outliers}

A test was conducted to determine the effect of outliers on the model with interaction effects included. When applying the M Estimation method, one data point was indicated as an outlier. The application of the LTS method identified five data points as outliers. The deletion of these data resulted in models with $R^{2}$ s of 0.80 and 0.90 , respectively. The adjusted $R^{2}$ s increased to 0.76 and 0.88 , respectively. 
The resulting models are very similar to the previously discussed model. The deletion of the five outliers indicated by the LTS method resulted in noteworthy changes in the parameter estimates of the independent variables Indicator_Lim_ln_x50 and Indicator_FS_ln_x33 included in the interaction model without independent outliers.

Table 6 contains the parameter estimates and descriptions of the effects, included in all three models, on the dependent variable. It is assumed that all other interaction effects remain constant.

Table 6

Descriptions of the interaction effects of the HT data set

\begin{tabular}{|c|c|c|c|c|c|}
\hline \multirow[b]{2}{*}{ Variable } & \multirow[b]{2}{*}{ Variable description } & \multicolumn{3}{|c|}{$\begin{array}{l}\text { Parameter estimates - } \\
\text { interaction model: }\end{array}$} & \multirow[b]{2}{*}{ Description of effect } \\
\hline & & Overall & $\begin{array}{l}\text { Without } \\
\text { dependent } \\
\text { outliers }\end{array}$ & $\begin{array}{c}\text { Without } \\
\text { independent } \\
\text { outliers }\end{array}$ & \\
\hline $\begin{array}{l}\text { Indicator_WC } \\
\text { _In_x49 }\end{array}$ & $\begin{array}{l}\text { In_x49 }=\ln \text { (provincial surplus } \\
\text { or deficit / provincial } \\
\text { payments) }\end{array}$ & -19.85 & -19.71 & -18.54 & $\begin{array}{l}\text { Negative parameter estimate } \\
\text { shows that increase in In_x49 } \\
\text { (provincial surplus or deficit / } \\
\text { provincial payments) leads to an } \\
\text { improvement in payment behaviour } \\
\text { for Western Cape }\end{array}$ \\
\hline $\begin{array}{l}\text { x27_grouped__ } \\
\text { Indicator_x36_z }\end{array}$ & $\begin{array}{l}\text { x27_grouped }=\text { departmental } \\
\text { annual appropriation of } \\
\text { revenue } / \text { total departmental } \\
\text { revenue (grouped) } \\
\text { Indicator_x36_Z }=0 \text { if depart- } \\
\text { mental net assets }=0,=1 \text { if } \\
\text { departmental net assets }>0\end{array}$ & -0.62 & -0.66 & -0.58 & $\begin{array}{l}\text { Increase in departmental annual } \\
\text { appropriation of revenue / total } \\
\text { departmental revenue leads to an } \\
\text { improvement in payment } \\
\text { behaviour, provided that the } \\
\text { department's assets > liabilities }\end{array}$ \\
\hline $\begin{array}{l}\text { Indicator_Lim__ } \\
\text { In_x36_Zmean }\end{array}$ & $\begin{array}{l}\text { In_x36_Zmean = } \\
\text { In(departmental net assets / } \\
\text { departmental total } \\
\text { expenditure) (missing mean) }\end{array}$ & -0.60 & -0.59 & -0.93 & $\begin{array}{l}\text { Increase in this variable leads to a } \\
\text { deterioration of payment behaviour } \\
\text { for Limpopo }\end{array}$ \\
\hline $\begin{array}{l}\text { Indicator_KZN_ } \\
\text { In_x48 }\end{array}$ & $\begin{array}{l}\text { In_x48 = In(provincial surplus } \\
\text { or deficit / provincial receipts) }\end{array}$ & -32.18 & -31.99 & -30.85 & $\begin{array}{l}\text { KwaZulu-Natal's payment } \\
\text { behaviour improves if the surplus } \\
\text { or deficit / provincial receipts ratio } \\
\text { improves }\end{array}$ \\
\hline $\begin{array}{l}\text { Indicator_Mpu_ } \\
\text { In_x57 }\end{array}$ & $\begin{array}{l}\text { In_x57 }=\ln (\text { provincial GDP } \\
\text { per capita) }\end{array}$ & -0.15 & -0.20 & -0.15 & $\begin{array}{l}\text { Increase in provincial GDP per } \\
\text { capita is beneficial to } \\
\text { Mpumalanga's Department of } \\
\text { Health's payment behaviour }\end{array}$ \\
\hline $\begin{array}{l}\text { Indicator_Lim_ } \\
\text { In_x50 }\end{array}$ & $\begin{array}{l}\text { In_x50 }=\ln \text { (provincial total } \\
\text { receipts / provincial total } \\
\text { payments) }\end{array}$ & -65.09 & -66.26 & -128.57 & $\begin{array}{l}\text { Increase in In_x50 leads to better } \\
\text { payment behaviour; this only } \\
\text { applies to the Limpopo province }\end{array}$ \\
\hline $\begin{array}{l}\text { Indicator_FS_ } \\
\text { In_x33 }\end{array}$ & $\begin{array}{l}\text { In_x33 = In(departmental } \\
\text { surplus or deficit / } \\
\text { departmental total revenue) }\end{array}$ & -22.70 & -22.00 & -34.79 & $\begin{array}{l}\text { Free State's Department of } \\
\text { Health's payment behaviour will } \\
\text { improve if its surplus or deficit / } \\
\text { total revenue improves }\end{array}$ \\
\hline $\begin{array}{l}\text { x27_grouped_ } \\
\text { In_x34 }\end{array}$ & $\begin{array}{l}\text { x27_grouped = departmental } \\
\text { annual appropriation of } \\
\text { revenue / total departmental } \\
\text { revenue (grouped) } \\
\text { In_x34 = In(departmental } \\
\text { surplus or deficit / } \\
\text { departmental total } \\
\text { expenditure) }\end{array}$ & -13.93 & -15.1 & -13.69 & $\begin{array}{l}\text { Payment behaviour will improve as } \\
\text { In_x34 increases, provided that } \\
\times 27 \text { has high values (group }=1 \text { ). } \\
\text { Where } x 27 \text { has low values (group } \\
=-1 \text { ) an increase in departmental } \\
\text { surplus or deficit / departmental } \\
\text { total expenditure leads to } \\
\text { worsening payment behaviour. } \\
\text { Remainder of values of } x 27 \text { (group } \\
=0 \text { ) have no effect due to } \\
\text { multiplication by } 0\end{array}$ \\
\hline
\end{tabular}

\subsection{Health without time data set $(\mathrm{H})$}

The stepwise model of the $\mathrm{H}$ data set was used to test for improvements in the model if subject knowledge is used as a variable-selection method, if interaction effects are added to the model, and if outliers are deleted from the data set. These results are presented next. 


\subsubsection{Subject knowledge as a variable-selection method}

The model including variables representing all four broad factors' $R^{2}$ improves from 0.49 to 0.53 , but the prediction accuracy should be measured as well.

\subsubsection{Outliers}

Three data points were identified as outliers in the dependent variable. The $R^{2}$ of the model improved from 0.49 to 0.68 , and the adjusted $R^{2}$ from 0.44 to 0.65 , when these data points were deleted.

The LTS technique indicated four data point as outliers. The deletion of these data points improved the model's $R^{2}$ and adjusted $R^{2}$ even more to 0.72 and 0.69 , respectively. The model improved considerably in terms of the increase in $R^{2}$, that is, by 39 per cent and 46 per cent, respectively. However, the loss of data must be considered. Again, the parameter estimates did not change much.

\subsubsection{Interaction effects}

The test done to determine whether the inclusion of interactions effects will improve the model was repeated for the $\mathrm{H}$ data set. The results are presented in Table 7.

Table 7

Model including interaction effects of the $\mathrm{H}$ data set

\begin{tabular}{|l|c|c|c|c|}
\multicolumn{1}{|c|}{ Variable } & 0.62 & Adj. $R^{2}$ & 0.56 \\
\hline & Parameter & Standardised estimate & $\begin{array}{c}\text { Variance } \\
\text { p-value } \\
\text { inflation } \\
\text { factor }\end{array}$ \\
\hline Intercept & 0.91 & 0.00 & $<.0001$ & 0.00 \\
\hline x27_grouped_In_x57 & -0.05 & -0.32 & $<0.01$ & 1.08 \\
\hline Indicator_KZN_In_x49 & -34.78 & -0.65 & $<.0001$ & 1.08 \\
\hline Indicator_Lim_In_x36_Zmean & 0.63 & 0.39 & $<0.01$ & 1.12 \\
\hline Indicator_Mpu_In_x58 & 0.51 & -0.27 & 0.01 & 1.06 \\
\hline Indicator_WC_In_x13 & -0.30 & -0.31 & 0.01 & 1.06 \\
\hline Indicator_Lim_In_x50 & -53.33 & -0.29 & 0.01 & 1.07 \\
\hline
\end{tabular}

As in the case of the HT data set, the resulting model contains only interaction variables, except for the intercept. The $R^{2}$ improved from 0.49 to 0.62 . Again, only high-level descriptions are provided seeing that the inclusion of interaction terms resulted in a complicated model (Table 7). These descriptions are based on the assumption that all other variables stay constant.

\subsubsection{Combining the effect of interaction effects and outliers}

When applying the $\mathrm{M}$ Estimation method to the $\mathrm{H}$ interaction model, six data points were indicated as outliers. The application of the LTS method identified four data points as outliers.

The $R^{2}$ of the model increased from the original 0.62 to 0.85 once the data points with the dependent-variable outliers were deleted. The $R^{2}$ increased from the original 0.62 to 0.82 when the four data points with outliers in the independent space were deleted.

These models are similar to the interaction model. Once again, the parameter estimate of the independent variable Indicator_Lim_ln_x50 included in the interaction model without independent outliers showed a large change. Therefore, the outliers did have a noteworthy effect in this model. This relates to the HT interaction model without independent outliers.

Table 8 contains the high-level descriptions of the interaction terms, indicated by the parameter estimates, on the dependent variable. 
Table 8

Descriptions of interaction terms included in the $\mathrm{H}$ data set

\begin{tabular}{|c|c|c|c|c|c|}
\hline \multirow[b]{2}{*}{ Variable } & \multirow[b]{2}{*}{ Variable description } & \multicolumn{3}{|c|}{$\begin{array}{l}\text { Parameter estimates - } \\
\text { interaction model: }\end{array}$} & \multirow[b]{2}{*}{ Description of effect } \\
\hline & & Overall & $\begin{array}{l}\text { Without } \\
\text { dependent } \\
\text { outliers }\end{array}$ & $\begin{array}{c}\text { Without } \\
\text { independent } \\
\text { outliers }\end{array}$ & \\
\hline $\begin{array}{l}\text { x27_grouped_ } \\
\text { In_x57 }\end{array}$ & $\begin{array}{l}\text { x27_grouped = } \\
\text { departmental annual } \\
\text { appropriation of revenue } \\
\text { / total departmental } \\
\text { revenue (grouped) } \\
\text { In_x57 = In(provincial } \\
\text { GDP per capita) }\end{array}$ & -0.05 & -0.05 & -0.04 & $\begin{array}{l}\text { Payment behaviour improves as In_x57 } \\
\text { increases, provided that } \times 27 \text { has high } \\
\text { values (group }=1 \text { ). Where } \times 27 \text { has low } \\
\text { values, (group }=-1 \text { ) increases in } \\
\text { provincial GDP per capita lead to } \\
\text { worsening payment behaviour. The } \\
\text { remaining values of } x 27 \text { (group }=0 \text { ) } \\
\text { have no effect due to multiplication by } 0\end{array}$ \\
\hline $\begin{array}{l}\text { Indicator_KZN_ } \\
\text { In_x49 }\end{array}$ & $\begin{array}{l}\text { In_x49 = In(provincial } \\
\text { surplus or deficit / } \\
\text { provincial payments) }\end{array}$ & -34.78 & -31.05 & -32.06 & $\begin{array}{l}\text { Negative parameter estimate shows } \\
\text { that increase in In_x49 (provincial } \\
\text { surplus or deficit / provincial payments) } \\
\text { leads to an improvement in payment } \\
\text { behaviour in KwaZulu-Natal }\end{array}$ \\
\hline $\begin{array}{l}\text { Indicator_Lim_In_ } \\
\text { x36_Zmean }\end{array}$ & $\begin{array}{l}\text { In_x36_Zmean }= \\
\text { In(departmental net } \\
\text { assets / departmental } \\
\text { total expenditure) } \\
\text { (missing mean) }\end{array}$ & 0.63 & 0.59 & 1.08 & $\begin{array}{l}\text { Increase in In_x36_Zmean leads to a } \\
\text { deterioration of payment behaviour for } \\
\text { Limpopo }\end{array}$ \\
\hline $\begin{array}{l}\text { Indicator_Mpu_ } \\
\text { In_x58 }\end{array}$ & $\begin{array}{l}\text { In } \times 58=\ln \text { (provincial } \\
\text { GDP per capita growth) }\end{array}$ & -0.51 & -0.63 & -0.76 & $\begin{array}{l}\text { Increase in provincial GDP per capita } \\
\text { growth is beneficial to Mpumalanga }\end{array}$ \\
\hline $\begin{array}{l}\text { Indicator_WC_ } \\
\text { In_x13 }\end{array}$ & $\begin{array}{l}\text { In_x13 = In(departmental } \\
\text { capital expenditure / } \\
\text { departmental adjusted } \\
\text { budget) }\end{array}$ & 0.3 & -0.35 & -0.33 & $\begin{array}{l}\text { Increase in In_x13 leads to an } \\
\text { improvement in payment behaviour of } \\
\text { Western Cape }\end{array}$ \\
\hline $\begin{array}{l}\text { Indicator_Lim_ } \\
\text { In_x50 }\end{array}$ & $\begin{array}{l}\text { In_ } x 50=\ln (\text { provincial } \\
\text { total receipts / provincial } \\
\text { total payments) }\end{array}$ & -53.33 & -44.66 & -121.13 & $\begin{array}{l}\text { Increase in In_x50 results in better } \\
\text { payment behaviour for Limpopo }\end{array}$ \\
\hline
\end{tabular}

\subsection{Summary}

Section 4 investigated linear-regression models to improve the $R^{2}$ values via three modeladvancement techniques, that is, using subject knowledge as a variable-selection method, including interactions between the independent variables in the models and excluding outliers from the data. The inclusion of additional independent variables, based on the subject knowledge variable-selection method, improved the $R^{2} \mathrm{~s}$ of the models. The inclusion of interactions effects and the deletion of outliers improved the models.

\section{Subnational credit ratings and their policy implications in South Africa}

Given the contribution of a workable system to evaluating and assigning subnational credit ratings, government may well employ the developed models (Sections 3 and 4) in order to assess the creditworthiness of its underlying subnationals. This may have policy implications. While the focus of this paper was not to recommend or direct specific government policy, this section nevertheless discusses potential policy implications.

The problem of inconsistent reports or data formats exists in South Africa. An example of data that were considered for this paper, but which could not be used because of changing report formats, is the information on unauthorised expenditure and irregular expenditure, as well as the fruitless and wasteful expenditure information found in the Auditor-General's reports. The consolidated general report on provincial audit outcomes from 2010 to 2011 (Auditor General, 2011) contains summaries of this information on a departmental level (see Table 23:49). Although some of this information is also documented in the "Consolidated general report on provincial audit outcomes 2009-10", it was documented in a different format (Fourie et al., 2013:95-96).

Another problem relating to the data sources used is the availability of data. In theory, the historical records should be easy to access. However, in practice, these are often difficult to 
procure. Also, these should ideally be available at least quarterly in order to update the credit ratings on a regular basis once the developed credit-rating methodologies are finalised. However, most of the data available to update subnational credit-rating methodologies in South Africa are made available only once a year.

National Treasury could consider amending current policies to include more rigid guidelines on reporting so as to overcome the inconsistent reporting. It is also suggested that the policies on financial reporting be amended in such a manner that all information is available on a more regular basis, as well as being made available electronically. This is confirmed by Rodden (2006) who observes that one of the most promising aspects of moving towards enhanced fiscal surveillance of regional and local governments is the collection of better data.

Another data problem that has been identified is that the information on the outstanding amounts on debt obligations and the number of days/months that they have been outstanding does not exist for provincial governments and departments (owing to the fact that South Africa's provincial governments and departments use a cash-based accounting system instead of an accrual-based accounting system). These data provide information on a provincial department's willingness and capability to repay debt obligations in full and on time, which is the general measure used by credit-rating agencies when assessing creditworthiness. It would be best if this information were to be included in provincial governments and departments' financial reports.

It would also be preferable for provincial governments and departments to make use of the accrual-based accounting system, since this would result in more comprehensive and comparable financial statements. In 2001, the International Monetary Fund (IMF) recommended that the accrual-based accounting system should be used for all government financials (IMF, 2001). The National Treasury confirmed in its budget review document that national and provincial governments employ a modified cash-based accounting system, while local authorities (municipalities) and public entities use the accrual-based accounting system. It declared its intention to follow the IMF's recommendation over time, but stated that government data would be presented on a cash basis for the immediate future (National Treasury, 2013b:1-2).

Subnational governments could use the developed methodology and models (Sections 3 and 4) to identify areas in which they can improve. An indirect benefit would be more effective management owing to the resultant competition among provincial governments. This may influence future departmental policies.

Additional possible policy implications are evident when considering specific variables that were important in most of the models developed. Note that most of the variables used come from the broad factor, fiscal performance (see, for example, Figure 2), and that the developed methodologies would therefore most probably influence fiscal policies. Ter-Minassian (2007:2-3) states that fiscal policies on a subnational level will be influenced greatly by the central government's policy. Fiscal rules are often seen as devices to ensure fiscal discipline. Fiscal rules are neither necessary nor sufficient to ensure fiscal discipline at the subnational level. In principle, both financial markets and cooperative arrangements across government levels could promote such discipline and provide the right incentives for local politicians to be fiscally responsible. However, fiscal rules could be useful when these arrangements are not feasible or fully reliable. Nevertheless, fiscal rules cannot secure fiscal discipline by themselves if the political will to adhere to them is lacking, or if the central government's commitment to a no-bailout policy is not credible.

For example, as the fiscal performance variable x27_grouped (departmental annual appropriation of revenue to total departmental revenue) increases, the payment behaviour of the department improves. The fiscal policy determining departmental appropriation of revenue should be reviewed in order to encourage departments to increase own revenue generation. Ways to increase the Department of Health's own revenue might be to implement departmental (or provincial) tax as opposed to national tax. This, however, should be undertaken with extreme caution. This warning is confirmed by the literature. Rodden (2006) states that, as subnational governments in Europe gain greater independence over larger shares of public-sector budgets, it may seem that they gain greater access to domestic and international credit markets too. As a 
result, subnational debt markets are expanding rapidly and an increasing number of subnational governments are being credit-rated. This may seem like a good opportunity to enhance the efficiency of local infrastructural investment and build a more central role for markets. However, scepticism about increasing market discipline among the subnational governments remains, since most of Europe's subnational governments are highly dependent on shared taxes and grants. Rodden (2006) argues that credit markets are poorly suited to exercising discipline over the borrowing of subnational governments that do not have sufficient access to independent taxation.

Another fiscal performance variable Indicator x 36 Z reflects that departments with net assets are better payers than departments without net assets. Generally, the existence of net assets, that is, a situation where assets exceed liabilities, indicates good financial management. Thus departments with net assets will be in a better position to make repayments in a timely manner. AustraliaRatings (2014) also views asset management as part of its financial-management strategy assessment. Again, fiscal policies could be amended to address this, but the rating assigned to the subnational government is unlikely to be taken seriously by investors if there are considerable policy uncertainties and doubts about the strength and quality of the institutions and systems within which the credit analysis is conducted (Liu \& Tan, 2009:29). The policymaking process is often less transparent and the likelihood of frequent policy changes much stronger in developing countries than in developed countries (Liu \& Tan, 2009:32).

\section{Conclusions and suggestions for future research}

\subsection{Conclusions}

Although none of the defined South African subnationals are currently being rated, the three largest international credit-rating agencies do rate South Africa's national government. If the credit ratings resulting from the proposed methodology will not be used on an international level, the effect of the sovereign rating on the subnationals' credit rating may be neglected, since the national government will have the same effect on all nine subnationals.

It should be noted that municipal governments are credit-rated. All 278 South African municipalities are rated by Municipal IQ, a data and intelligence service specialising in the monitoring and assessment of South Africa's municipalities (Municipal IQ, 2013). Fitch and Moody's also rate the municipalities, but only a few (less than 5 per cent).

A concern when developing a subnational credit-rating methodology is data availability as well as data quality. Section 2 revealed three possible data sources that could be used within the South African context: (1) the subnational government's annual reports (South African Government Information, 2013); (2) the Auditor-General's reports (Auditor-General of South Africa, 2011); and (3) the Section 32 reports (National Treasury of South Africa, 2013a) compiled by the National Treasury.

This paper's main contribution is to develop the quantitative section of a credit-rating methodology for South African subnationals. The unique characteristics of the available data, the assembly of these data, and the selection of dependent and independent variables for the linearregression model chosen were presented and discussed in Section 2.

The second contribution is that the methodology was then applied to provincial Departments of Health. This resulted in three linear-regression models being built in Section 3 explaining 51 per cent, 49 per cent and 48 per cent of the variation (measured by $R^{2}$ ) of the payment behaviour of the Department of Health. The most influential variable was Indicator_KZN indicating that the Department of Health of Kwazulu-Natal is a better payer than the other provinces' Departments of Health.

More complexed linear models were built in Section 4, increasing the $R^{2}$ to 74 per cent, 62 per cent, 82 per cent and 85 per cent, respectively, and clearly improving the models.

Some of the observations (measured by absolute value in estimates) included the following: 
- Increases in the ratio departmental net assets/departmental total expenditure leads to a deterioration of payment behaviour for Limpopo's Department of Health (Table 6).

- KwaZulu-Natal's payment behaviour improves if the surplus or deficit/provincial receipts ratio improves (Table 6).

The third and last contribution is the construction of the data sets, which are available on request. The data used to develop the quantitative section of the credit-rating methodology were discussed in Section 2. Six different reports, compiled by four institutions, were used to gather five years' data. This equated to 70 different reports and one interactive data set being used to compile two data sets.

\subsection{Future research}

The number of provincial departments per provincial government differs. In theory, it should be possible to aggregate the data at a provincial-government level in order to develop a provinciallevel, subnational credit-rating methodology, but, in practice, the unequal number of departments poses difficulties in terms of data collection and aggregation. This might be an avenue to investigate further in future.

The improvements in the models built in Section 4 should be tested by assessing the appropriateness of each model (in terms of prediction accuracy) when deciding whether the improvement in $R^{2}$ is worthwhile. The increase in complexity of the models (when including interaction effects and the loss of data when deleting outliers) must also be taken into account. These improvements are planned for future research.

The methodology developed in this paper was applied to the Department of Health. The methodology may be applied to other departments as well. Once the IMF's recommendation is implemented (that the accrual-based accounting system be used for all government financials), more comprehensive financial statements should be available. This will enable the redevelopment of the methodology so as to include other data as well.

Owing to the nature of the data used, the subnational credit-rating methodologies developed in this study assess only quantitative information. It is therefore recommended that future research address the identification and quantification of qualitative information that could be used to determine the credit quality of South Africa's subnationals.

In this paper, linear regression was chosen as the modelling technique. A further step could be to compare different modelling techniques with linear regression.

\section{Endnote}

1 This work is based on research supported in part by the National Research Foundation of South Africa [reference number UID: TP1207243988]. The grant holder acknowledges that opinions, findings and conclusions or recommendations expressed in any publication generated by NRF-supported research are those of the author(s) and that the NRF accepts no liability whatsoever in this regard.

\section{References}

AUDITOR-GENERAL. 2007 to 2011. Consolidated general reports on the national and provincial audit outcomes 2006/07 to 2010/11. Auditor-General of South Africa, Pretoria.

AUSTRALIA RATINGS. 2014. State territory government methodology. Available at: http://www.australiaratings.com/stateterritorygovernmentmethodology [accessed February 2014]. CHAMBERS, M. \& DINSMORE, T.W. 2014. Predictive analytics techniques. New Jersey: Pearson Education, FT Press.

DBRS. 2011. Methodology: Rating Canadian provincial governments. Toronto: Dominion Bond Rating Service Limited, DBRS.

FIELD, A. 2005. Discovering statistics using SPSS ( $2^{\text {nd }}$ ed.) London: Sage.

FITCH. 2011. International local and regional governments rating criteria: Outside the United States. New York: Fitch Ratings. 
FOURIE, E., STYGER, P., DE LA REY, T. \& VAN VUUREN, G. 2013. Review of subnational credit rating methodologies and the applicability in the South African context. Politeia, 32(3):74-99.

HAIR, J.F., BLACK, W.C., BABIN, B.J., ANDERSON, R.E. \& TATHAM, R.L. 2006. Multivariate data analysis $\left(6^{\text {th }}\right.$ ed.) Pearson: Prentice Hall.

HWANG, R.-C., CHUNG, H. \& CHU, C. 2010. Predicting issuer credit ratings using a semiparametric method. Journal of Empirical Finance, 17(1):120-137.

IMF. 2001. International Monetary Fund, 2001. Available at: https://www.imf.org/external/pubs/ft/gfs/ manual/pdf/all.pdf [accessed June 2016].

KUTNER, M.H., NACHTSHEIM, C.J., NETER, J. \& LI, W. 2005. Applied linear statistical models $\left(5^{\text {th }}\right.$ ed.) New York: McGraw-Hill/Irwin.

LIU, L. \& TAN, K. 2009. Subnational credit ratings: A comparative review. Policy research working paper 5013 .

LIU, L. \& WAIBEL, M. 2008. Macro federalism and local financing, insolvency and regulation. Washington DC: World Bank.

MOODY'S. 2006. Moody's credit rating prediction model. London: Moody's Investors Service.

MOODY'S. 2007. Bank financial strength ratings: Global methodology. London: Moody's Investors Service.

MOODY'S. 2008. Rating methodology: Regional and local governments outside the US. Updated rating methodology. London: Moody's Investors Service.

MOODY'S. 2014. A survey of regression method as proxy functions. Available at:

http://www.moodysanalytics.com//media/Insight/Regulatory/Solvency-II/Thought-Leadership/2014/201424-03-A-Survey-of-Regression-Methods.ashx [accessed August 2014].

MUNICIPAL IQ. 2013. Available at: www.municipaliq.co.za [accessed July 2013].

NATIONAL TREASURY. 2007 to 2011. Provincial statements of receipts and payments for the 4th quarter ended 31 March 2007 to 2011. National Treasury of South Africa, Pretoria.

NATIONAL TREASURY. 2012. Workshop discussing: Preliminary results of risk grading of provincial governments. National Treasury of South Africa, Pretoria, 8 November 2012.

NATIONAL TREASURY. 2013a. Fourth quarter year to date provincial budgets and expenditure report (preliminary outcome) 2012/13. National Treasury of South Africa, Pretoria.

NATIONAL TREASURY. 2013b. Structure of the government accounts. Website annexure to the 2013 Budget Review. National Treasury of South Africa. Available at: http://www.treasury.gov.za/documents/ national [accessed August 2013].

NATIONAL TREASURY. 2013c. Workshop discussing: A proposed credit rating methodology for South African provincial governments. National Treasury of South Africa, Pretoria, 30 May 2013.

NOVOTNA, M. 2012. The use of different approaches for credit rating prediction and their comparison $\left(6^{\text {th }}\right.$ ed.) International Scientific Conference Managing and Modelling of Financial Risks. Ostrava, VŠB-TU Ostrava, Faculty of Economics, Finance Department 10th-11th September 2012. Available at: http://www.ekf.vsb.cz/ export/sites/ekf/rmfr/.content/galerie-dokumentu/2014/sbornik/Novotna.Martina.pdf [accessed October 2015].

OSBORNE, J.W. (ed.) 2008. Best practices in quantitative methods. California: Sage.

PALLANT, J. 2007. SPSS survival manual. ( $3^{\text {rd }}$ ed.) England: McGraw-Hill.

RODDEN, J. 2006. Achieving fiscal discipline in federations: Germany and the EMU. Available at: http://web.stanford.edu/ jrodden/rodden_brussels.pdf [accessed November 2015].

SANCHE, R. AND LONERGAN, K. 2006. Variable reduction for predictive modelling with clustering, Casualty Actuarial Society Forum (Winter) 2006:89-100.

SAS INSTITUTE INC. 2010. Predictive modelling using logistic regression course notes, SAS Institute Inc., SAS2010, Cary, NC.

SAS INSTITUTE INC. 2011. The SAS system for Windows release 9.3 TS level 1M0. SAS Institute Inc., SAS2011, Cary, NC.

SOUTH AFRICA. 2006. Regulations made in terms of the National Credit Act, 2005 (Act No 34 of 2005). Available at: http://www.ncr.org.za/pdfs/The\%20National\%20Credit\%20Regulations.pdf [accessed August 2014]. 
S\&P. 2009. General criteria: Understanding standard \& poor's rating definitions. New York: McGraw-Hill. S\&P. 2010. Methodology for rating international local and regional governments. New York: McGraw-Hill. STATS SA. 2012. Mid-year population estimates by province, gender, age group and year. Available at: www.statssa.gov.za [accessed November 2012].

STATS SA. 2013. Gross domestic product. Annual estimates 2003-2012. Regional estimates 2003- 012. Third quarter 2013. Statistical release P0441, Statistics South Africa, Pretoria.

TER-MINASSIAN, T. 2007. Fiscal rules for subnational governments: Can they promote fiscal discipline? Available at: http://www.oecd.org/gov/budgeting/43469443.pdf [accessed November 2015].

WARNER, R.M. 2008. Applied statistics from bivariate through multivariate techniques. California: Sage. 